\title{
Expression of Glycosyl Hydrolases in Lignocellulosic Feedstock: An Alternative for Affordable Cellulosic Ethanol Production
}

\author{
Yao Xiao $^{1}$ - Charleson Poovaiah ${ }^{1}$ - Heather D. Coleman ${ }^{1}$ \\ Published online: 22 June 2016 \\ (C) The Author(s) 2016. This article is published with open access at Springerlink.com
}

\begin{abstract}
Ethanol produced from lignocellulosic feedstock is a promising alternative to fossil fuels and corn-sourced ethanol. However, it creates unique challenges in terms of requirements for breakdown to fermentable sugars, including the need for pretreatment and enzymatic hydrolysis of structural carbohydrates. Hydrolases from microorganisms are currently utilized for biomass hydrolysis in the production of lignocellulosic ethanol; however, expressing these hydrolases in lignocellulosic feedstock is a favorable alternative, due to the large availability of biomass and the potential for the feedstock to play a dual role as both biomass substrate and enzyme provider. This review summarizes recent achievements in hydrolytic enzyme expression in a variety of model plants and potential feedstocks, including strategies to improve enzyme yield and to prevent deleterious effects on plants hosts. We propose possible scenarios for utilizing enzyme-expressing transgenic feedstock and illustrate the potential benefits of using these crops for ethanol production. Furthermore, challenges are highlighted and potential solutions proposed to move the field forward to cost-comparable lignocellulosic ethanol.
\end{abstract}

Keywords Biofuel $\cdot$ In planta expression $\cdot$ Enzymatic hydrolysis $\cdot$ Cellulases $\cdot$ Biomass $\cdot$ Autohydrolysis

Heather D. Coleman

hcoleman@syr.edu

Yao Xiao

yxiao07@syr.edu

Charleson Poovaiah

crpoovai@syr.edu

1 Biology Department, Syracuse University, 107 College Place, Syracuse, NY 13244, USA

\section{Introduction}

Growing energy consumption and declining fossil fuel supply are critical energy issues facing the global population. Fossil fuel combustion unavoidably produces greenhouse gases such as $\mathrm{CO}_{2}$ and methane ultimately affecting the global climate [1]; uneven distribution of energy supplies among countries and huge global energy demands lead to energy security problems [2]. Environmental and national security concerns, as well as a clear limitation in resources, drive the need for prompt development of sustainable alternative energy resources.

One such alternative resource, in the form of plant-derived liquid fuel, has been gaining increasing consideration from government, industry, and academia [3]. Biofuels produced from the fermentation of plant-derived sugars provide a renewable source for fossil fuel supplementation [4]. Sources of fermentable sugars from plants are classified into two categories. First generation biofuels are derived primarily from food crops such as corn and sugarcane. Large-scale use of the starch and sugar from these crops for energy production contributes to a perceived conflict with food production. Second generation biofuels are produced from nonfood lignocellulosic biomass, from sources including dedicated bioenergy crops and agricultural residues. Theoretically, lignocellulosic biofuels have advantages over first generation biofuels in that they avoid the use of a food crop and source a much larger spectrum of biomass [5]. However, challenges remain in the large-scale production of second generation biofuels, mainly due to the recalcitrance of the plant cell wall. There are no cost-effective technologies currently available to breakdown complex cell wall structures to release fermentable sugars [5]. Globally, among six companies that are currently producing cellulosic ethanol, Raizen, a Brazil based company utilizing sugarcane bagasse, has the lowest projected minimum ethanol 
selling price at $\$ 2.17 /$ gal (Lux Research; http://www. luxresearchinc.com/). This is significantly higher than the price of corn ethanol at \$1.5/gal in 2015 (United States Department of Agriculture Economic Research Service; http://www.ers.usda.gov/).

Despite a goal of 21 billion gallons of biofuels from noncornstarch sources by 2022 [6], only 142 million gallons of cellulosic biofuel was produced in 2015 in the USA (2015 Renewable Fuel Standard data from United States Environmental Protection Agency; www.epa.gov). This falls far below the anticipated industry growth rate that is required to achieve the mandated target. Indeed, even globally, the challenge of meeting renewable fuel goals is so far unattainable, and it is questionable whether these goals will achieve the attempt to limit climate change to less than $2{ }^{\circ} \mathrm{C}$ [7].

Despite abundant biomass availability, there are a number of economic challenges associated with lignocellulosic fuel production. These challenges arise as a result of the complexity of lignocellulose. There are three major components in lignocellulosic biomass: cellulose, hemicellulose, and lignin [8]. Cellulose is a homo-polysaccharide consisting of glucose linked by $\beta$-1,4-glycosidic bonds. The linear cellulose chains form a crystalline microfibril structure through internal and external hydrogen bonds. Hemicelluloses are complex heterogeneous polysaccharides composed of various types of monomer sugars including glucose, xylose, mannose, arabinose, galactose, and glucuronic acid. There are a variety of hemicelluloses dependent on plant species and tissue type [9]. In some hemicellulose structures, the side residues are methylated or acetylated. The third major component in lignocellulose, lignin, is composed of three aromatic monomers-guaiacyl monomers (G-lignin), syringyl monomers (S-lignin), and $p$ hydroxyphenyl monomers (H-lignin). The cellulose microfibrils are embedded in a matrix of lignin and hemicellulose, which blocks the access of enzymes to cellulose [10]. Many of the challenges associated with the breakdown of the cell wall for biofuels production are directly attributable to the complexity of the wall structure.

One of the significant costs associated with the breakdown and utilization of lignocellulosic biomass is that of the enzymes required for the hydrolysis of cellulose to fermentable glucose $[11,12]$. Three classes of cellulases work synergistically to breakdown cellulose into glucose. Endo-1,4- $\beta$ glucanases (EC 3.2.1.4) hydrolyze internal $\beta$-1,4-glycosidic bonds randomly and cleave long cellulose chain into small fragments; exo-1,4- $\beta$-glucanases (EC 3.2.1.91) release cellobiose units from the chain ends; $\beta$-glucosidase (EC. 3.2.1.21) hydrolyzes cellobiose and cello-oligosaccharides to release glucose monomers [13]. In addition, xylanases and other accessory enzymes such as acetyl xylan esterase and ferulic esterase hydrolyze xylan, which in many species is the most abundant hemicellulose component [14]. These accessory enzymes significantly enhance the performance of cellulases and improve enzymatic hydrolysis [15-17]. Currently, cell wall hydrolytic enzymes are produced for commercial purposes in microorganisms, including bacteria such as Bacillus subtilis [18] and fungal systems such as Trichoderma reesei [19]. Commercial enzymes produced using these systems continue to be too expensive for commercial lignocellulosic ethanol production to become cost-competitive with fossil fuels $[20,21]$; cellulase costs were identified as a key driver in keeping ethanol prices below the minimum profit point and alternative cellulase production is suggested as a solution [20]. Strategies to overcome this barrier during biomass production are essential for increasing biofuel yields and reducing production cost.

While extensive research is focused on enhancing these microbe-produced enzymes and their production systems $[19,21,22]$, an alternative platform has been identified: the production of cell wall-degrading enzymes in planta [23]. Expression of recombinant proteins in plants holds numerous advantages over microbe-expression systems including production scale-up and compatible eukaryotic posttranslational modification [24, 25]. Microbial enzyme production requires large capital investment and constant productionmonitoring [26]. In addition, hydrolytic enzymes produced from microbe expression platforms often exhibit low activity due to differing post-translational processes from that of the original organism [27]. Even the use of eukaryotic fungal hosts can be problematic for production of correctly glycosylated enzymes whose function and activity is highly dependent on post-translation modification. For example, overexpression of Trichoderma reesei cellobiohydrolase Cel7A in Aspergillus niger resulted in an over-glycosylated version of the protein with a resultant low enzymatic activity toward known substrates [28]. However, Cel7A was successfully expressed in maize and shown to retain its activity [29].

Several studies have been carried out that support the development of plant-based enzyme production. These include studies showing expression levels up to $26 \%$ total soluble protein (TSP) in Arabidopsis and 50\% TSP in tobacco leaves [29-37]. Although there is potential for high-level enzyme production in these plant systems, the expression of cell wall-degrading enzymes in the biomass of the lignocellulosic feedstocks themselves has added advantages [38]. Production of enzymes in the biomass feedstock would allow one crop to serve as both an enzyme provider and a biomass substrate for enzymatic saccharification.

Several plant species have been identified as potential commercial lignocellulosic bioenergy crops. These crops have common advantageous traits including producing large amounts of biomass in a short time period, having established maintenance and management systems, and playing a limited role as food [39]. For instance, seeds of traditional cereal crops can be used for food, while the remaining biomass can be 
utilized for ethanol production [40]. Currently, many agricultural crops such as corn and rice produce vast amounts of lignocellulosic material that is mainly disposed of by burning or left on the field after harvest [41]. While some material, such as sugarcane bagasse post-sugar extraction, is used to produce electricity [42], there is evidence that the further utilization of these agricultural residues to produce ethanol or other liquid transport fuels would add tremendous value to modern agricultural production [43]. In addition, dedicated feedstocks exist that could be grown as crops for the purpose of biofuels production. Tree species, such as poplar and willow, could be planted as biomass crops on marginal land. These trees share characteristics, such as fast growth rate, easy propagation, and high biomass production in a short time, that make them suitable as bioenergy crops [44, 45]. Perennial grasses such as switchgrass, reed canary grass, Napier grass, and Bermuda grass have low fertilizer requirements and established management systems, making them suitable for the production of biomass for biofuels [46].

Expressing cell wall-degrading enzymes in the biofuels feedstock itself has promising potential for reducing the cost of lignocellulosic ethanol production (Fig. 1). Here, we describe three scenarios for plants producing high levels of cellulolytic enzymes. The "basic scenario" is to directly utilize transgenic feedstocks as enzyme providers. Enzymes extracted from transgenic plants will be added to reactors for cellulose hydrolysis. Plant expressed glycosyl hydrolases will complement exogenous cellulases and hemicellulases.

An improvement over this is the "advanced scenario," in which hyperthermophilic glycosyl hydrolases are expressed in the biofuel crop itself. Hyperthermophilic enzymes will be activated at high temperature, during pretreatment, allowing enzymatic saccharification and pretreatment to be conducted in the same reactor [38]. In both scenarios (basic and advanced), reduced amounts of microbe produced exogenous cellulases and hemicellulases will be required to release equivalent amounts of fermentable sugars. The expression levels and diversity of glycosyl hydrolases produced in planta would determine the amount of exogenous enzyme loading required.

The final scenario, or the "ideal scenario," would see exogenous enzymes completely replaced with feedstock-derived enzymes, requiring the enzymes be produced in planta at a high enough level and with the variety of enzymes required for complete hydrolysis. The ideal scenario would allow for pretreatment, saccharification, and fermentation in a single reactor, requiring both thermophilic enzymes and thermophilic fermentation microorganisms. This scenario will also require work to resolve technical issues such as removal of inhibitory compounds and utilization of non-fermented chemicals. In addition, it will require field validation of high level expression of glycosyl hydrolases in biofuel crops.

\section{Expression of Glycosyl Hydrolases in Plants}

The expression of enzymes in plants has improved significantly during the last two decades, both in terms of expression levels and activity. Early on, Ziegler et al. [37] produced an Arabidopsis line with $26 \%$ of the TSP being attributed to the overexpression of catalytic domains of an Acidothermus cellulolyticus endoglucanase targeted to the apoplast, but there have been few studies that have been able to replicate such

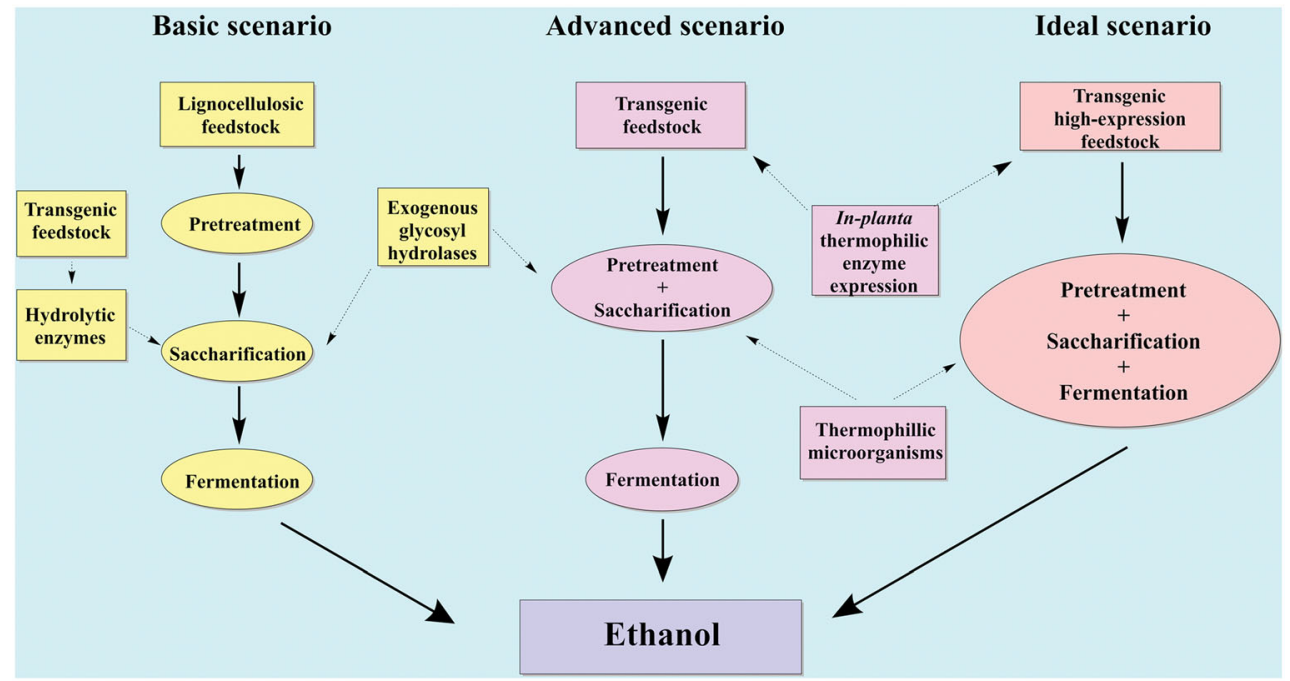

Fig. 1 Three scenarios for utilizing feedstock expressing glycosyl hydrolases. In the "basic scenario," proteins are extracted from transgenic feedstock and added to enzymatic saccharification. In the "advanced scenario," hyperthermophilic enzymes are produced in bioenergy crops. The feedstock undergoes pretreatment and saccharification in the same reactor. In the "ideal scenario," hyperthermophilic enzymes are produced in bioenergy crops and pretreatment, saccharification, and fermentation are performed in a single reactor. There is no additional requirement for exogenous hydrolases 
success. The high expression level in this study was attributed to several cis-elements, specifically the cauliflower mosaic virus $35 \mathrm{~S}$ promoter, the tobacco mosaic virus $\Omega$ translational enhancer, the polyadenylation signal sequence, and the apoplast target sequence [37]. Other studies have obtained moderate levels of recombinant protein by using seedspecific promoters to drive expression in the endosperm. Acidothermus cellulolyticus endoglucanases were accumulated to over $16 \%$ seed TSP in maize seed [29]. These levels of expression have also been shown to be stable over generations [34]. Despite these successes, in order for the expression of enzymes in planta to be effective, significantly higher expression levels are required or the enzymes must be produced more universally throughout the plant to increase per plant enzyme production.

\section{Strategies to Increase Expression Level of Glycolytic Enzymes in Plants}

With growing interest in the area of in planta heterologous protein expression, strategies and technologies to enhance expression levels have become more prevalent. Regulation of in planta hydrolytic enzyme expression involves transcriptional, post-transcriptional, translational, and post-translational processing modification steps [25], and each of these provides an opportunity for improving in planta expression.

Perhaps, the most direct target for modification is the DNA sequence of the hydrolytic enzyme to be overexpressed. All current hydrolytic proteins proposed for lignocellulosic ethanol production are from microorganisms, which have distinctive codon usage compared to that of plants. Codon usage bias has been shown to affect protein expression in non-origin hosts, with codon optimization of genes for the host species resulting in improved expression levels [47]. For example, when the Bacillus thuringiensis delta endotoxin gene was codon optimized for expression in tobacco and tomato, in planta recombinant protein production level was increased by $100-$ fold [48]. Synthetic genes, codon optimized for their target species, have been used for the in planta expression of glycosyl hydrolases to achieve high expression levels [29, 49]. Although there is no direct comparison in literature between in planta expression of codon-optimized versus non codonoptimized hydrolytic enzymes, evidence from previous studies support the use of codon optimized genes for improved expression level of hydrolytic enzymes in planta [48, 50].

During the last decade, numerous cis-elements have been evaluated for their ability to enhance expression levels of transgenes [51]. One of the most essential cis-elements is the promoter chosen for gene expression. For the purpose of this paper, we characterize promoters into the following three categories: constitutive, tissue-specific, and inducible [52]. Each category of promoter has been used to drive glycosyl hydrolases expression, which is reviewed by Taylor et al. [25].
The cauliflower mosaic virus $35 \mathrm{~S}$ promoter is the most studied constitutive promoter in dicot plants and has been widely used to express hydrolytic enzymes [31, 37, 53]. Expression levels of up to $26 \%$ TSP in Arabidopsis have been achieved with this promoter. The synthetic Mac promoter is another commonly used constitutive promoter for hydrolytic protein production in various plant species including tobacco, potato, rice, sugarcane, and alfalfa [54-56]. Expression levels comparable to that of $35 \mathrm{~S}$ have been achieved.

Tissue-specific promoters have also been used for in planta glycosyl hydrolase expression. The maize globulin-1 promoter and the rice glutelin promoters, targeting the seed/endosperm, have been used to drive expression of hydrolytic enzymes in corn kernels and rice grain [29, 35, 49, 57]. Tissue-specific levels of Acidothermus cellulolyticus endoglucanase up to $16 \%$ TSP have been achieved in maize using these promoters [29]. The green tissue specific promoter from the rubisco small subunit ( $\mathrm{rbcS}$ ) has also been successfully used for expression of cellulases [30,58] with TSP levels of $5.2 \%$ in tobacco. Tissue-specific heterologous enzyme expression has certain conveniences for plant processing, including stability and convenience of harvest. Hydrolase activity in corn kernels and rice grains has been shown to be stable during post-harvest storage [49, 57]. Hydrolytic enzymes can be harvested simultaneously with biomass substrate if they are expressed in leaf tissue providing some benefits for cellulosic ethanol production.

Inducible promoters are activated by specific inducers including environmental signals and applied chemicals. They provide additional benefits for in planta glycosyl hydrolase expression, including reduced deleterious effects on the plant hosts and controlled timing of expression. By taking advantage of the knowledge produced in the past two decades, expression of glycosyl hydrolases in planta could be targeted to specific plant organs and controlled in terms of timing by utilizing specific promoters and targeting sequences available for recombinant protein expression in plants. So far, there is no systematic comparison among the ability of different types of promoters for overexpression of recombinant proteins in plants. While there is variability, some studies have shown that tissue specific promoters drive higher expression than constitutive promoters in potato [30], and the CaMV 35S promoter leads more to protein production than the ethanol inducible promoter in tobacco [59].

In addition to promoters, other cis-elements including untranslated leaders (UTLs) are essential for recombinant protein expression in planta, as they contribute to stability of the transcript and efficiency of translation initiation [60]. $5^{\prime}$ untranslated leader sequences are presumed to bind to $40 \mathrm{~S}$ ribosomal subunits, which migrate and recognize the start codon for translation [61]. A synthetic 5' UTL from alfalfa mosaic virus (AMV) has been evaluated and confirmed to boost expression levels of recombinant proteins in plants $[62,63]$. The 
AMV 5' UTL has been used to improve expression of endoglucanase in both potato and tobacco [54, 64].

An alternative approach that has also resulted in high expression levels of recombinant proteins in planta is plastid transformation [65]. Plastid transformation takes advantage of the large number of multi-genome plastids in a plant cell $[66,67]$. After integration of the desired genes into the plastid genome, genes of interest will replicate during plastid replication and cell division, resulting in the desired gene being highly transcribed and the desired protein produced at a high level. Integration of glycosyl hydrolase genes from Thermotoga maritima into the chloroplast genome of tobacco resulted in expression levels up to $9 \%$ TSP [68].

The utilization of DNA regulatory elements and advanced plant transformation technology has provided proof of concept for high level glycosyl hydrolase expression in plants. These results inform future work into the area of high level cellulase expression in biofuel feedstocks.

\section{Strategies to Prevent Harmful Effects of Glycosyl Hydrolase Expression on Plant Hosts}

Cellulose and surrounding hemicellulose are essential components of the plant cell wall. These structural polysaccharides, the source of carbohydrates for biofuels production, are essential for normal plant growth and development; it is key that when expressing the hydrolytic enzymes responsible for their breakdown that normal plant development is not adversely effected. There are a number of examples in which transgenic plants overexpressing hydrolases show reduced growth and abnormal physiological phenotypes including stunted growth and reduced fertility $[59,69,70]$. Specific examples include transgenic tobacco expressing mesophilic glycosyl hydrolases having shorter stems, delayed flowering, and decreased cellulose levels [59] and thermostable cellulolytic enzyme expression in the chloroplast rendering severe pigment deficiency to tobacco plants resulting in insufficient photosynthesis and slow growth [69]. To avoid these detrimental effects, several strategies have been used for in planta hydrolytic enzyme production.

Temporal separation of enzyme production and plant growth can prevent the negative effects of hydrolases on plants [71]. The use of inducible expression systems allows for regulation of expression such that proteins are only produced in the presence of a chemical or environmental signal. Ideal inducible systems result in high expression after specific induction and have no expression prior to induction. In addition, inducing chemicals should be environmentally benign, and economical both in terms of production and application. Based on the above criteria, suitable inducers for large scale in planta hydrolase production may include ethanol [59, 72], post-harvest heat inducible platforms [73], or developmental signals including senescence $[74,75]$. These inducible expression systems would avoid problems associated with the cellulolytic activities toward the plant cell wall.

Organelle targeting is an alternative approach that allows high enzyme expression with low plant growth penalty. Subcellular organelle targeting is accomplished by applying specific target peptides attached to the proteins' C- or N-terminus. Studies show that targeting enzymes to subcellular organelles including the apoplast, endoplasmic reticulum, and vacuole resulted in increased accumulation and stability of glycosyl hydrolases [29, 31, 54] without a reduction in growth or altered development $[31,56]$. For example, apoplast targeted Acidothermus cellulolyticus endoglucanase resulted in protein accumulating to 100 -fold more than non-targeted cytosolic expression [31]. Similarly, targeting Trichoderma reesei cellobiohydrolase I (CBH I) to the cell wall in maize kernels resulted in accumulation to more than $16 \%$ TSP [29]. Besides achieving hyperexpression of recombinant hydrolytic proteins, subcellular organelle targeting also prevents interference from heterologous proteins.

An additional technology that allows for high level expression of cellulolytic enzymes in plants without detriment to growth and development is the use of enzymes from thermophilic sources. Thermophilic cell wall-degrading enzymes with optimal temperatures over $50{ }^{\circ} \mathrm{C}$ can be expressed in plants without disrupting cell wall integrity because they tend to perform poorly in normal plant growth conditions [76]. Hydrolases from thermophilic microorganisms such as Acidothermus cellulolyticus and Thermomonospora fusca, which are able to hydrolyze cellulose at high temperatures $\left(81\right.$ and $75^{\circ} \mathrm{C}$ respectively), have been expressed in various plant species with no harmful effects [37, 56, 77-79], while still having the desired effect of improving the ease of breakdown of plant material after harvest. Moreover, thermophilic enzymes are activated during post-harvest processing providing more advantages and applications in cellulosic ethanol production including simplifying processing and reducing exogenous enzyme loading [38].

Although high enzyme expression has been achieved in Arabidopsis and tobacco, their poor feasibility for biofuel production excludes them from being plant hosts for cell walldegrading enzymes in the context of the ideal scenario (Fig. 1). Lignocellulosic feedstocks are more suitable as hosts for hydrolytic enzyme production as they cannot only be the source of the hydrolytic enzymes but also serve as the source of the cellulosic biomass to be reduced to fermentable sugars. During ethanol production, enzymes expressed in the lignocellulosic biomass can reduce, or even obviate, the addition of expensive glycosyl hydrolases. Currently, however, most of the research on high-level hydrolytic enzyme expression focuses on the Arabidopsis and tobacco rather than lignocellulosic biomass. Without applying the strategies discussed above to lignocellulosic feedstocks, in planta glycosyl hydrolases production will be less likely to improve the costefficiency of ethanol production. 


\section{Expression of Glycosyl Hydrolases in Lignocellulosic Feedstock}

Feedstocks with established genetic modification technology such as maize, rice, sugarcane, and poplar have been successfully transformed to express cell wall-degrading enzymes [55, $77,79,80]$. Several examples of expression of cell walldegrading enzymes in lignocellulosic biomass feedstock are provided in Table 1. Although these examples would provide appropriate biomass and enzymes for the advanced scenario (Fig. 1), achieving levels necessary for the ideal scenario will require additional advances.

\section{Lignocellulosic Feedstocks Are an Ideal Source for Recombinant Hydrolytic Enzyme Production}

There is significant evidence that lignocellulosic crops, as a biofactory for glycosyl hydrolase production, could produce enough enzymes to replace microbial-produced enzymes, even with only moderate expression levels (TSP). This is due to the availability of large amounts of lignocellulosic biomass. For instance, 428 million tons dry matter of agricultural residue are produced every year [88]. This could afford 85,600 tons of enzyme to be produced from the agricultural residue at the moderate expression level of $1 \%$ TSP. Toward this goal, plant produced enzymes have proven effective in hydrolyzing plant biomass. For example, plant produced recombinant glycosyl hydrolases can hydrolyze natural cellulosic biomass such as corn stover and rice straw [69, 78]. Furthermore, several studies have shown that protein extracted from glycosyl hydrolase expressing transgenic plants can supplement exogenous enzymes during enzymatic hydrolysis [56, 77, 78]. Cellobiohydrolases expressed in corn were shown to enhance the performance of commercial cellulases in the degradation of pretreated sugarcane bagasse

Table 1 Summary of cellulosic biomass feedstock expressing glycosyl hydrolases

\begin{tabular}{|c|c|c|c|c|c|c|}
\hline Biomass feedstock & Cell wall-degrading enzymes & Source organism & Promoter & Subcellular target & Expression level & Reference \\
\hline \multirow[t]{3}{*}{ Rice straw } & Endoglucanase (E1) & $\begin{array}{l}\text { Acidothermus } \\
\text { cellulolyticus }\end{array}$ & CaMV 35S & Apoplast & $4.9 \%$ leaf TSP & {$[77]$} \\
\hline & Endoglucanase (E1) & $\begin{array}{l}\text { Acidothermus } \\
\text { cellulolyticus }\end{array}$ & Mac & Apoplast & $6.1 \%$ leaf TSP & {$[56]$} \\
\hline & $\begin{array}{l}\text { Xylanase } \\
\text { Catalytic domain }\end{array}$ & $\begin{array}{l}\text { Clostridium } \\
\text { thermocellum }\end{array}$ & CaMV 35S & Cytoplasm & NM & {$[81,82]$} \\
\hline \multirow[t]{2}{*}{ Maize stalk } & $\begin{array}{l}\text { Endoglucanase (E1) } \\
\text { Catalytic domain }\end{array}$ & $\begin{array}{l}\text { Acidothermus } \\
\text { cellulolyticus }\end{array}$ & CaMV 35S & Apoplast & $2.1 \%$ leaf TSP & [79] \\
\hline & $\begin{array}{l}\text { Endoglucanase (E1) } \\
\text { Catalytic domain }\end{array}$ & $\begin{array}{l}\text { Acidothermus } \\
\text { cellulolyticus }\end{array}$ & CaMV 35S & Apoplast & $1.13 \%$ leaf TSP & [78] \\
\hline \multirow[t]{3}{*}{ Sugarcane } & $\begin{array}{l}\text { Cellobiohydrolase } \\
\text { CBHI }\end{array}$ & Penicillium sp & Maize PepC & $\begin{array}{l}\text { ER, vacuole, } \\
\text { chloroplast }\end{array}$ & NM & {$[55,83]$} \\
\hline & $\begin{array}{l}\text { Cellobiohydrolase } \\
\text { CBHI }\end{array}$ & Trichoderma sp. & Maize PepC & $\begin{array}{l}\text { ER, vacuole, } \\
\text { chloroplast }\end{array}$ & & \\
\hline & Endoglucanase (E1) & & Maize PepC & $\begin{array}{l}\text { ER, vacuole, } \\
\text { chloroplast }\end{array}$ & & \\
\hline \multirow[t]{2}{*}{ Poplar } & Xylanase & Trichoderma reesi & CaMV 35S & Apoplast & $14.4 \%$ leaf TSP & {$[80]$} \\
\hline & Glucuronoyl esterase & $\begin{array}{l}\text { Phanerochaete } \\
\text { carnosa }\end{array}$ & CaMV 35S & Cell wall & NM & [84] \\
\hline \multirow[t]{3}{*}{ Alfalfa (Medicago sativa) } & Ferulic acid esterase & Aspergillus niger & tCUP 4 & $\begin{array}{l}\text { Apoplast, } \\
\text { chloroplast, } \\
\text { ER, vacuole }\end{array}$ & NM & {$[85]$} \\
\hline & Endoglucanase (E2) & Thermomonospora & Mac & Cytosol & $0.01 \%$ leaf TSP & {$[53]$} \\
\hline & Exoglucanase (E3) & fusca & Mac & Cytosol & $\begin{array}{l}0.001-0.002 \% \\
\text { leaf TSP }\end{array}$ & \\
\hline \multirow[t]{3}{*}{$\begin{array}{l}\text { Tall fescue } \\
\qquad \text { (Festuca arundinacea) }\end{array}$} & Xylanase & Trichoderma reesei & LmSee1 & Apoplast & $\begin{array}{l}200-400 \mathrm{U} / \mathrm{mg} \\
\text { fresh leaf }\end{array}$ & {$[86]$} \\
\hline & Ferulic acid esterase & Aspergillus niger & $\begin{array}{l}\text { Rice actin } \\
\text { promoter }\end{array}$ & Apoplast vacuole & NM & {$[75]$} \\
\hline & Xylanase & Trichoderma reesei & LmSee1 & Apoplast & & \\
\hline $\begin{array}{l}\text { Purple false brome } \\
\text { (Brachypodium distachyon) }\end{array}$ & Acetylesterases & Aspergillus nidulans & CaMV 35S & Apoplast & NM & [87] \\
\hline
\end{tabular}

Abbreviations: CaMV 35S cauliflower mosaic virus 35S RNA promoter, Lmseel Lolium multiflorum senescence promoter, Maize PepC maize phosphoenolpyruvate carboxylase promoter, ER endoplasmic reticulum, TSP total soluble protein, NM not measured 
[83]. In this same study, tap water was used as a solvent to recover recombinant cellulases from senescent leaf tissue at a rate of $90 \%$.

Even though there are no commercial plant-derived glycosyl hydrolases at the current time, plant expressed cellulolytic enzymes hold considerable potential to reduce the cost of enzymes during saccharification and contribute to affordable lignocellulosic ethanol $[25$,$] . Currently, commercial cellu-$ lases from Novozymes are reported to contribute to ethanol price at $\$ 0.5 / \mathrm{gal}$ [20]. Onsite cellulase production has been investigated to replace commercial cellulases and is predicted to reduce the cost of enzyme to $\$ 0.34 / \mathrm{gal}$ [89]. The goal price for enzymes is $\$ 0.1 / \mathrm{gal}$ [23].

Production of cellulolytic enzymes in lignocellulosic feedstock could further reduce the cost of enzymes. The cost of producing, extracting, and recovering rice-derived endoglucanases is currently estimated to be $\$ 9.64 / \mathrm{kg}$ enzymes $(\$ 0.64 / \mathrm{gal})$ under the condition that $5 \%$ TSP of endoglucanases is produced from rice straw [77]. Although this estimated cost is still far higher than the target price $(\$ 0.1 /$ gal), the situation could be improved by increasing expression of enzymes in planta and decreasing cost of enzyme extraction and recovery. The price could reduce in half $(\$ 0.32 / \mathrm{gal})$ merely by doubling the expression level of enzymes to $10 \%$ TSP. More importantly, when plants expressing glycosyl hydrolases serve as a feedstock for ethanol production, the enzymes produced in planta will be of tremendous additional value, by removing the cost of exogenous commercial enzymes for ethanol production.

\section{Glycosyl Hydrolase Expressing Plants Can Have More Easily Digested Cell Walls}

Benefits of expressing glycosyl hydrolases in lignocellulosic biomass are not limited to just that of enzyme production. Importantly, expression of hydrolytic enzymes can result in modified plant cell wall composition, resulting in improved biomass degradation $[74,75,84$, 90]. For example, one study reported that in tall fescue expressing fungal ferulic acid esterase and xylanase, cell wall components changed in a way that the amount of esterified cell wall ferulate monomers and dimers, arabinose and xylose, were reduced. The altered cell wall composition resulted in the release of more fermentable sugars after enzymatic hydrolysis [75]. Several studies on maize, tall fescue, and alfalfa expressing cellulolytic enzymes reported that transgenic plants have higher glucan conversion than non-transgenic plants after thermochemical pretreatment and enzymatic digestion [74, 75, 85, 90, 91]. These results indicate that expressing cell wall-degrading enzymes in biomass crops can have positive effects on saccharification efficiency, which allows for more ethanol production.

\section{Utilizing Feedstocks Expressing Glycosyl Hydrolases Reduces Required Severity of Pretreatment}

Expressing glycosyl hydrolases in lignocellulosic biomass can also result in transgenic plants requiring less severe pretreatment to remove lignin and render the cellulose accessible to hydrolysis [90, 91]. For example, stover from corn plants expressing an endocellulase required pretreatment at only $140{ }^{\circ} \mathrm{C}$ to result in a saccharification efficiency comparable to that of wild-type material pretreated at $170{ }^{\circ} \mathrm{C}$ [90]. Currently, pretreatment utilizes high temperature and/or harsh acidic or alkaline chemicals to breakdown the cell wall structure and remove lignin or hemicellulose. Utilization of more mild pretreatments would reduce the cost of pretreatment, which contributes more than $20 \%$ of the cost of lignocellulosic ethanol production [92]. As a result, expressing cellulolytic enzymes in the lignocellulosic biomass would have a profound impact on the ethanol production from lignocellulosic feedstock not just in supplying the hydrolytic enzymes but also in reducing the cost and severity of required pretreatments.

Previous work on in planta expression of cell walldegrading enzymes has revealed two major potential benefits for cellulosic ethanol production. First, transgenic plants can be used as a molecular biofactory for production of cellulases/ hemicellulases for hydrolyzing lignocellulosic material. Second, when cell wall-degrading enzymes are expressed in the cellulosic feedstock, a reduced amount of hydrolytic enzymes and less severe pretreatments are required during the cellulosic bioethanol production. Utilizing transgenic cellulosic crops expressing cellulolytic enzymes as biofuels feedstock could lower energy and enzyme usage and costs.

\section{The Future of Hydrolytic Enzyme Expression in Feedstocks}

Despite success achieving moderately high expression levels of hydrolytic enzymes in multiple biomass feedstocks, with improved saccharification results in some of these crops, there is still much to be done in order to make autohydrolyzing lignocellulosic crops a reality. In order to generate real change, there are five hurdles that need to be addressed.

\section{Identification of Glycosyl Hydrolases Adapted to Pretreatment Conditions}

Pretreatment is a key step that serves to alter the structure of lignocellulosic biomass and provide access to the cellulose for hydrolysis. Current pretreatment technologies apply one or more of heat, acid, alkaline, or organic solvent to disrupt biomass recalcitrance [93]. Glycosyl hydrolases that can retain their activity and function in these conditions are essential to 
the process if pretreatment and saccharification are to be carried out simultaneously. However, few glycosyl hydrolases have been identified that are compatible with the conditions of pretreatment.

A number of different conditions are combined in pretreatment of lignocellulosic material. High temperature can be used together with acid or alkaline in a variety of formats including hot water pretreatment, dilute acid pretreatment, and ammonia recycle percolation pretreatment. Temperatures above $120^{\circ} \mathrm{C}$ are required during all of these pretreatment technologies [94]. However, most identified hyperthermophilic glycosyl hydrolases are functional only up to a maximum of approximately $100{ }^{\circ} \mathrm{C}$ [95]. The $\mathrm{pH}$ of current acid or alkaline pretreatments is inconsistent with the optimal $\mathrm{pH}$ of most glycosyl hydrolases. For instance, dilute acid pretreatment requires a $\mathrm{pH}$ below 2 and lime pretreatment is above $\mathrm{pH} 12$ [96, 97]. This is well beyond the $\mathrm{pH}$ range of most well-characterized cellulases and hemicellulases which, in the instances of Trichoderma reesei and Aspergillus niger, span $\mathrm{pH} 3.5$ to $5.0[95,98]$. Although some glycosyl hydrolases have been discovered that are tolerant to acidic or alkaline condition $[99,100]$, the utility of these enzymes for lignocellulosic ethanol production has not been assessed.

Organosolv pretreatment requires less severe temperatures and can be conducted below $100{ }^{\circ} \mathrm{C}$ [101]. The organic chemicals used during the pretreatment, including ethylene and glycerol, have negative impacts on glycosyl hydrolase activity [102]. Recently, some organic solvent resistant glycosyl hydrolases were discovered and characterized [100, 103]. Their potential during ethanol production is yet to be determined.

Ionic liquid (IL) pretreatment is perhaps the most promising option for combining with saccharification, due to the low temperature requirement and moderate $\mathrm{pH}$ range (4.8-6.5) [104, 105]. Hydrophilic ILs, such as 1-butyl-3-methylimidazolium chloride and 1-allyl-3-methylimidazolium chloride, are applied to dissolve cellulose. ILs have been tested in combination with cellulases, with one study showing that cellulases retain $30 \%$ activity in the presence of $10 \%(v / v)$ 1,3-dimethylimidazolium dimethylphosphate [105]. Several glycosyl hydrolases have been discovered to be tolerant to IL treatments [106, 107]. These enzymes are good candidates for in planta expression, and transgenic plants could be processed with IL pretreatment for ethanol production.

In order to take advantage of plant produced enzymes, the identification of additional extremophile glycosyl hydrolases is needed, and the full characterization of existing enzymes is required. One option is discovery of native enzymes in extremophiles, but perhaps a more realistic approach will be the engineering of existing enzymes to improve function and stability in the various extreme conditions of pretreatment [108].

\section{Cross Species Differences in Phenotypic Effects of Gene Expression}

Most studies expressing recombinant glycosyl hydrolases have been performed on plants that are not potential lignocellulosic biomass feedstocks, such as Arabidopsis and tobacco $[30-32,37]$. It is worth noting that there are significant differences between cell wall structure and composition of potential biofuels feedstocks, let alone differences from model plants. Arabidopsis is distinctive from woody plants in terms of physiology and genetics $[109,110]$ and has a significantly lower proportion of secondary cell wall than woody plants [111]. Additionally, the cell wall composition is divergent between species, whether model species or potential feedstocks [112]. For instance, xyloglucan is the major hemicellulose in Arabidopsis, whereas glucuronoarabinoxylan and glucuronoxylan are predominant in grass and hardwood trees, respectively [9]. It is likely that glycosyl hydrolase expression in different plant species will result in crop-specific effects on plant processing during ethanol production. For example, expression of fungal glucuronyl esterase in Arabidopsis and poplar had different effects on cell wall composition. Transgenic poplar trees had higher lignin and lower carbohydrate contents than non-transgenic trees [84]. However, when expressing the same heterologous glucuronyl esterase in Arabidopsis, reduced carbohydrates but similar lignin contents were observed in transgenic lines compared to wild types [113]. Although this difference may be the result of subcellular targeting, the expression of the same gene in different plants has often resulted in different phenotypic effects [90]. When it comes to sugar release after saccharification without pretreatment, the transgenic poplar trees produced significantly less carbohydrates relative to controls, whereas the transgenic Arabidopsis released slightly higher amounts of sugars compared to non-transgenic plants $[84,113]$.

These studies illustrate the effect of differences in cell wall composition and sugar yield between transgenic plant species expressing the same hydrolytic enzyme. Without expressing hydrolytic enzymes in the lignocellulosic biomass of interest, it is not possible to directly translate the results from other species and to determine how hydrolytic enzyme expression in feedstocks will affect efficiency of ethanol production.

\section{Taking Feedstocks Through to Field Trials}

To date, there are no reports of field trials of transgenic lignocellulosic feedstocks expressing glycosyl hydrolases. All published work on glycosyl hydrolase expression has been carried out under controlled conditions in tissue culture or greenhouse experiments. Field evaluation is essential for confirmation of positive and negative traits of glycosyl hydrolase-expressing transgenic feedstocks [114]. These lines must be assessed in the field to confirm both the maintenance of the desired trait 
and whether the plants are capable of enduring biotic and abiotic stresses. This is particularly important as the plant cell wall is closely associated with plant defense $[115,116]$. Genes involving lignin biosynthesis have been found to play important roles in plant defense [117, 118]. In Arabidopsis, members of the cinnamyl alcohol dehydrogenases (CAD) gene family, one of the key genes in lignin biosynthesis, were induced by pathogen attack. Moreover, cad mutant lines displayed decreased resistance to pathogens [118]. In addition to differences in pathogen resistance, plants with modified cell walls can also have altered abiotic stress resistance. Arabidopsis cinnamoyl-CoA reductase 1 (CCR1) mutants with reduced lignin content were more sensitive to UV damage [119]. These studies indicate that modifications that alter plant cell wall composition or structure could cause changes in plant stress resistance.

Previous results involving altered expression of lignin biosynthesis genes have revealed differences between greenhouse-grown and field-grown transgenic biomass feedstocks with modified cell wall structure. Baucher et al. [120] demonstrated that antisense cinnamyl alcohol dehydrogenase (CAD) alfalfa lines had lower reduction of CAD activity in the field than in the greenhouse. As a result, field-grown transgenic alfalfa did not display the same level of increased digestibility observed in greenhouse-grown transgenic plants. Besides differences in desired traits between greenhouseand field-grown transgenic plants, plant growth and survivability can vary between plants grown in these two environments. CCR down-regulated poplar had reduced growth compared to wild type in field studies despite a normal phenotype in greenhouse conditions [121]. Switchgrass overexpressing PvMYB4 had significantly reduced lignin content and grew well in greenhouse studies [122], but these same transgenic lines did not survive in field experiments [123]. The evidence implies that phenotype may vary between greenhouse and field experiments for plants with modified cell walls.

It is impossible to accurately assess the financial impacts of hydrolytic enzymes produced in planta on ethanol production without field trials. As there is variability between greenhouse and field conditions, it is key to identify lines with improved characteristics under field conditions, which may be different from the lines with improved characteristics in the greenhouse.

\section{Scalable Technologies}

A fourth challenge for the success of expression of hydrolytic enzymes in feedstock involves the use of scalable industrial processing technologies. Although there are a number of studies in which glycosyl hydrolases are expressed in lignocellulosic biomass feedstock, few studies have explored processing of biomass in a scalable manner to the final product of ethanol. Some studies report the processing of the transgenic biomass to the point of sugar conversion or ethanol production [84, 90, $91,113]$, but there is limited data to assess the effectiveness of glycosyl hydrolase expression on the cost of lignocellulosic ethanol. In order to move forward in a timely fashion, there needs to be a systematic approach to compare utilization of transgenic lignocellulosic biomass with non-transgenic biomass for ethanol production from the point of plant cultivation to the final carbohydrate fermentation to ethanol. A lack of research on direct processing of whole transgenic feedstock limits our knowledge of the final outcome of utilizing the glycosyl hydrolase expressing plants for ethanol production.

In vitro digestibility is enhanced in glycosyl hydrolase expressing feedstock to release more sugar compared to wild type $[75,85]$. However, few studies have reported processing transgenic feedstock using scalable technologies for pretreatment and saccharification, let alone measuring ethanol yield resultant from fermentation. Exceptions include Brunecky et al. [90] who demonstrated that transgenic maize expressing the Acidothermus cellulolyticus endoglucanase (E1) release more sugars than control plants after $1 \%$ sulfuric acid pretreatment and hydrolysis using commercial cellulases and Zhang et al. [91] who assessed the effect of hydrolytic enzyme expression on ethanol production after pretreatment and a simultaneous saccharification and fermentation (SSF) process.

When it comes to industrial production, it is essential to conduct robust investment analyses of ethanol production from transgenic feedstocks to access the market competitiveness of ethanol produced from this biomass. There is still a significant gap between current technologies and affordable cellulosic ethanol [20], and each facet, including plant maintenance and harvest, pretreatment, enzymatic saccharification, and fermentation, needs to be tailored for transgenic feedstock to gain the highest efficiency. These required steps are interrelated, and the processing of biomass through to ethanol production using scalable technologies is required in order to accurately assess the success of a transgenic line.

\section{The Need for Enhanced Specialized Expression Systems}

The final challenge lies in the drive for expression of cellulases in lignocellulosic feedstocks themselves. Achievable expression levels of recombinant cell wall hydrolases have been improved dramatically through subcellular targeting, synthetic promoters, and other strategies as summarized above. Despite these gains, most studies still report expression levels below $8 \%$ TSP in lignocellulosic biomass feedstocks (Table 1). It is hypothesized that recombinant cellulases hydrolyze cellulose completely at the standard condition of 15 filter paper unit (FPU) cellulases/g cellulose [124]. High expression levels of glycosyl hydrolases in lignocellulosic biomass are required to achieve full auto-hydrolysis in standard conditions. 
Table 2 Cellulase expression level required in poplar to achieve complete autohydrolysis

\begin{tabular}{ll} 
Cellulose content & $0.45 \mathrm{~g}$ cellulose $/ 1 \mathrm{~g}$ dry weight biomass \\
Cellulase required for cellulose degradation & $0.45 \mathrm{~g}$ cellulose $\times 15 \mathrm{FPU} / 1 \mathrm{~g}$ cellulose $=6.75 \mathrm{FPU}$ \\
& $(13 \mathrm{mg}$ cellulase $)$ \\
TSP content & $90 \mathrm{mg}$ \\
$\begin{array}{l}\text { Expression level of cellulase for complete } \\
\text { autohydrolysis }\end{array}$ & $\begin{array}{c}13 \mathrm{mg} \text { cellulases } / 90 \mathrm{mg} \mathrm{TSP} \times 100 \%=14.4 \% \mathrm{TSP} \\
\text { of cellulases }\end{array}$ \\
\hline
\end{tabular}

1FPU translates to $1.93 \mathrm{mg}$ cellulase [126]
Using poplar as an example, under the assumption that soluble proteins in poplar are about $90 \mathrm{mg} / \mathrm{g}$ dry weight [125] and cellulose in wood is $450 \mathrm{mg} / \mathrm{g}$ dry weight [44], it is anticipated that levels of more than $14 \%$ TSP cellulase will be required to be produced in and recovered from poplar leaf to completely hydrolyze host plant cellulose (Table 2).

Using published levels of cellulose and soluble proteins, we calculated required in planta expression levels of cellulases in poplar, rice straw, and switchgrass (Table 3 ) to achieve complete autohydrolysis under standard conditions (15 FPU cellulase/g cellulose). Here, we assume an enzyme recovery rate of $85 \%$, based on published recovery rates of functional xylanase from tobacco leaf [131]. At these levels, a minimum of $13 \%$ TSP expression level is required for in planta cellulases to degrade plant host cellulose (Table 3, rice straw). Although these numbers are generalized for all cellulases as opposed to each class required for complete biomass breakdown, the implication remains the same: in order to produce enough enzymes in planta, expression levels need to be increased significantly. Optimizing in planta recombinant protein expression in lignocellulosic biomass feedstock to achieve higher expression level is both a challenge and opportunity for lignocellulosic ethanol production.

The use of viral expression systems is a promising technology for hyperexpression of heterologous proteins in planta [132]. There are a variety of plant viruses that have been modified to act as vectors for recombinant protein expression in plants including both DNA [133] and RNA viruses [134]. The last two decades have witnessed significant improvements in plant virus expression vectors to overcome barriers such as instability in plant hosts and limited size of inserted gene sequence, which have been reviewed in literature with much detail [135-138]. Plant virus expression vectors inherit the replication mechanisms of the original virus $[136,139]$.
Genes of interest are replicated in the plant cells and produce high levels of proteins of interest such as biopharmaceutical proteins, when they are integrated into plant virus vectors and transferred into plant cells [139]. To date, most plant virus expression vectors have been used only in transient expression of foreign proteins [140, 141].

Recently, a new in planta recombinant protein expression platform has emerged, In Plant ACTivation (INPACT), which combines ethanol induction and a deconstructed geminivirus vector. INPACT is confirmed to highly express heterologous proteins after ethanol induction, achieving higher expression levels than traditional overexpression constructs using the constitutive CaMV 35S promoter [142]. INPACT incorporates plant virus vector expression and inducible expression; the former trait contributes to hyperexpression and the latter separates plant growth and desired protein production to avoid adverse effects of heterologous proteins on plants. Because of these two characteristics, INPACT provides a promising approach for in planta glycosyl hydrolase expression. In addition, INPACT technology is not host limited [142]. For this reason, we anticipate that systems such as INPACT will allow a variety of lignocellulosic biomass feedstocks to be utilized for high level enzyme expression as in the ideal scenario (Fig. 1). This type of high-level, inducible system and other potential high level expression systems including chloroplast expression and systems taking advantage of new technologies will be paramount in the use of lignocellulosic feedstocks as biofactories for the production of cellulolytic enzymes for their own breakdown.

While the expression of single enzymes in lignocellulosic feedstocks is underway, the accumulation of multiple glycosyl hydrolases in a single species will present an additional challenge. As more than one cellulase is required to hydrolyze cellulose to glucose, producing multiple glycosyl hydrolases
Table 3 Level of in planta cellulase expression required in poplar leaf, rice straw and switchgrass to completely hydrolyze host plant cellulose, assuming an $85 \%$ recovery rate

\begin{tabular}{llll}
\hline & Poplar leaf & Rice straw & Switchgrass \\
\hline Cellulose content & $45 \%$ d.w. [44] & $39 \%$ d.w. [127] & $30 \%$ d.w. [128] \\
Soluble proteins content & $9 \%$ d.w. [125] & $5-10 \%$ d.w. [129] & $7 \%$ d.w. [130] \\
In planta cellulases expression level & $17 \%$ TSP & $12.9-25.8 \%$ TSP & $14.5 \%$ TSP \\
\hline
\end{tabular}

Soluble protein content in rice straw depends on the age of rice leaves during senescence [129]

Abbreviations: d.w. dry weight, TSP total soluble protein 
in one plant would enhance the capability of in planta enzyme production and improve saccharification efficiency of utilizing transgenic plants for ethanol production. The expression of multiple glycosyl hydrolases could be achieved either by transferring multiple vectors containing individual transgenes into plant cell or by utilizing one vector containing multiple transgenes. There are few examples of expressing multiple cell wall-degrading enzymes in single plants $[75,143]$. In these studies, two functional glycosyl hydrolases are successfully produced. Based on this work, it appears possible and beneficial to shift from producing single enzymes to multiple in a plant. More research is necessary to generate transgenic plants expressing multiple glycosyl hydrolases and to assess the functionality of these plants for the levels of enzyme production required for ethanol production, as well as to assess any potential challenges that may arise from the production of multiple glycosyl hydrolases in one plant.

\section{Conclusion}

Ethanol production from lignocellulosic feedstocks has attracted global attention due to increasing demand for sustainable fuel sources and huge ethanol yield potential from lignocellulosic biomass. Economically, competitive lignocellulosic ethanol production is limited by biomass production and subsequent biomass conversion to fermentable sugars; the cost of glycosyl hydrolases is one of the cost barriers for use of lignocellulosic biomass. Although the cost of microbialderived hydrolytic enzymes is decreasing, the expression of hydrolytic enzymes in planta remains a promising alternative that continues to garner increased attention. Moreover, lignocellulosic feedstocks are ideal plant hosts for glycosyl hydrolase expression because of large availability of biomass and the potential for a dual role as both biomass substrate and enzyme provider. Previous research has shown that plants producing glycosyl hydrolases, either as a biofactory alone with the enzymes recovered for use, or as the transgenic biomass substrate to be converted to ethanol, could hold promise to reduce the cost of lignocellulosic ethanol production. More research is required to evaluate and improve the efficiency of using glycosyl hydrolase expressing transgenic feedstock for ethanol production, particularly taking the plant material right through processing to ethanol production and investigating the feasibility of transgenic feedstocks in the field. In addition, boosting expression levels of hydrolytic enzymes in feedstocks is an unavoidable requisite for utilizing transgenic feedstocks for the production of economically competitive lignocellulosic ethanol. Although several hurdles need to be overcome, glycosyl hydrolase production in lignocellulosic feedstock holds the capability to play a key role in meeting global renewable energy goals.
Open Access This article is distributed under the terms of the Creative Commons Attribution 4.0 International License (http:// creativecommons.org/licenses/by/4.0/), which permits unrestricted use, distribution, and reproduction in any medium, provided you give appropriate credit to the original author(s) and the source, provide a link to the Creative Commons license, and indicate if changes were made.

\section{References}

1. Hameed S, Dignon J (1988) Changes in the geographical distributions of global emissions of $\mathrm{NO} x$ and $\mathrm{SO} x$ from fossil-fuel combustion between 1966 and 1980. Atmos Environ (1967) 22(3):441-449

2. Asif M, Muneer T (2007) Energy supply, its demand and security issues for developed and emerging economies. Renew Sust Energ Rev 11(7):1388-1413

3. Sorda G, Banse M, Kemfert C (2010) An overview of biofuel policies across the world. Energ Policy 38(11):6977-6988

4. Lin Y, Tanaka S (2006) Ethanol fermentation from biomass resources: current state and prospects. Appl Microbiol Biotechnol 69(6):627-642

5. Stephen JD, Mabee WE, Saddler JN (2012) Will secondgeneration ethanol be able to compete with first-generation ethanol? Opportunities for cost reduction. Biofuels Bioprod Biorefin 6(2):159-176

6. Sissine F Energy Independence and Security Act of 2007: a summary of major provisions. In, 2007. DTIC Document

7. Jones GA, Warner KJ (2016) The 21 st century population-energyclimate nexus. Energ Policy 93:206-212

8. Limayem A, Ricke SC (2012) Lignocellulosic biomass for bioethanol production: current perspectives, potential issues and future prospects. Prog Energy Combust Sci 38(4):449-467. doi:10.1016/j.pecs.2012.03.002

9. Scheller HV, Ulvskov P (2010) Hemicelluloses. Annu Rev Plant Biol 61:263-289. doi:10.1146/annurev-arplant-042809-112315

10. Somerville C, Bauer S, Brininstool G, Facette M, Hamann T, Milne J, Osborne E, Paredez A, Persson S, Raab T (2004) Toward a systems approach to understanding plant cell walls. Science 306(5705):2206-2211

11. Lynd LR, Laser MS, Bransby D, Dale BE, Davison B, Hamilton R, Himmel M, Keller M, McMillan JD, Sheehan J (2008) How biotech can transform biofuels. Nat Biotechnol 26(2):169-172

12. Ragauskas AJ, Williams CK, Davison BH, Britovsek G, Cairney J, Eckert CA, Frederick WJ, Hallett JP, Leak DJ, Liotta CL (2006) The path forward for biofuels and biomaterials. Science 311(5760):484-489

13. Bhat M, Bhat S (1997) Cellulose degrading enzymes and their potential industrial applications. Biotechnol Adv 15(3):583-620

14. Dodd D, Cann IK (2009) Enzymatic deconstruction of xylan for biofuel production. GCB Bioenergy 1(1):2-17

15. Berlin A, Gilkes N, Kilburn D, Maximenko V, Bura R, Markov A Skomarovsky A, Gusakov A, Sinitsyn A, Okunev O (2006) Evaluation of cellulase preparations for hydrolysis of hardwood substrates. In: Twenty-seventh symposium on biotechnology for fuels and chemicals. Springer, Berlin Heidelberg New York, pp. 528-545

16. Berlin A, Gilkes N, Kilburn D, Bura R, Markov A, Skomarovsky A, Okunev O, Gusakov A, Maximenko V, Gregg D (2005) Evaluation of novel fungal cellulase preparations for ability to hydrolyze softwood substrates - evidence for the role of accessory enzymes. Enzym Microb Technol 37(2):175-184

17. Berlin A, Maximenko V, Gilkes N, Saddler J (2007) Optimization of enzyme complexes for lignocellulose hydrolysis. Biotechnol Bioeng 97(2):287-296 
18. Anderson TD, Robson SA, Jiang XW, Malmirchegini GR, Fierobe H-P, Lazazzera BA, Clubb RT (2011) Assembly of minicellulosomes on the surface of Bacillus subtilis. Appl Environ Microbiol 77(14):4849-4858

19. Den Haan R, Kroukamp H, van Zyl J-HD, van Zyl WH (2013) Cellobiohydrolase secretion by yeast: current state and prospects for improvement. Process Biochem 48(1):1-12

20. Liu G, Zhang J, Bao J (2016) Cost evaluation of cellulase enzyme for industrial-scale cellulosic ethanol production based on rigorous Aspen Plus modeling. Bioprocess Biosyst Eng 39(1):133-140

21. Mazzoli R, Lamberti C, Pessione E (2012) Engineering new metabolic capabilities in bacteria: lessons from recombinant cellulolytic strategies. Trends Biotechnol 30(2):111-119

22. Durand H, Clanet M, Tiraby G (1988) Genetic improvement of Trichoderma reesei for large scale cellulase production. Enzym Microb Technol 10(6):341-346

23. Sticklen $M$ (2006) Plant genetic engineering to improve biomass characteristics for biofuels. Curr Opin Biotechnol 17(3):315-319. doi:10.1016/j.copbio.2006.05.003

24. Twyman RM, Stoger E, Schillberg S, Christou P, Fischer R (2003) Molecular farming in plants: host systems and expression technology. Trends Biotechnol 21(12):570-578

25. Taylor LE, Dai Z, Decker SR, Brunecky R, Adney WS, Ding S-Y, Himmel ME (2008) Heterologous expression of glycosyl hydrolases in planta: a new departure for biofuels. Trends Biotechnol 26(8):413-424

26. Sukumaran RK, Singhania RR, Pandey A (2005) Microbial cellulasesproduction, applications and challenges. J Sci Ind Res 64(11):832

27. Lambertz C, Garvey M, Klinger J, Heesel D, Klose H, Fischer R, Commandeur U (2014) Challenges and advances in the heterologous expression of cellulolytic enzymes: a review. Biotechnol Biofuels 7(1):135

28. Jeoh T, Michener W, Himmel ME, Decker SR, Adney WS (2008) Implications of cellobiohydrolase glycosylation for use in biomass conversion. Biotechnol Biofuels 1(10)

29. Hood EE, Love R, Lane J, Bray J, Clough R, Pappu K, Drees C, Hood KR, Yoon S, Ahmad A (2007) Subcellular targeting is a key condition for high-level accumulation of cellulase protein in transgenic maize seed. Plant Biotechnol J 5(6):709-719

30. Dai Z, Hooker BS, Anderson DB, Thomas SR (2000) Expression of Acidothermus cellulolyticus endoglucanase E1 in transgenic tobacco: biochemical characteristics and physiological effects. Transgenic Res 9(1):43-54

31. Ziegelhoffer T, Raasch JA, Austin-Phillips S (2001) Dramatic effects of truncation and sub-cellular targeting on the accumulation of recombinant microbial cellulase in tobacco. Mol Breed 8(2):147-158

32. Yu L-X, Gray BN, Rutzke CJ, Walker LP, Wilson DB, Hanson MR (2007) Expression of thermostable microbial cellulases in the chloroplasts of nicotine-free tobacco. J Biotechnol 131(3):362-369

33. Devaiah SP, Requesens DV, Chang Y-K, Hood KR, Flory A, Howard JA, Hood EE (2013) Heterologous expression of cellobiohydrolase II (Cel6A) in maize endosperm. Transgenic Res 22(3):477-488

34. Hood EE, Devaiah SP, Fake G, Egelkrout E, Teoh KT, Requesens DV, Hayden C, Hood KR, Pappu KM, Carroll J (2012) Manipulating corn germplasm to increase recombinant protein accumulation. Plant Biotechnol J 10(1):20-30

35. Zhang Q, Zhang W, Lin C, Xu X, Shen Z (2012) Expression of an Acidothermus cellulolyticus endoglucanase in transgenic rice seeds. Protein Expr Purif 82(2):279-283

36. Hahn S, Giritch A, Bartels D, Bortesi L, Gleba Y (2015) A novel and fully scalable Agrobacterium spray-based process for manufacturing cellulases and other cost-sensitive proteins in plants. Plant Biotechnol J 13(5):708-716

37. Ziegler MT, Thomas SR, Danna KJ (2000) Accumulation of a thermostable endo-1, 4- $\beta$-D-glucanase in the apoplast of Arabidopsis thaliana leaves. Mol Breed 6(1):37-46
38. Mir BA, Mewalal R, Mizrachi E, Myburg AA, Cowan DA (2014) Recombinant hyperthermophilic enzyme expression in plants: a novel approach for lignocellulose digestion. Trends Biotechnol 32(5):281-289

39. Somerville C, Youngs H, Taylor C, Davis SC, Long SP (2010) Feedstocks for lignocellulosic biofuels. Science 329(5993):790 792

40. Yuan JS, Tiller KH, Al-Ahmad H, Stewart NR, Stewart CN (2008) Plants to power: bioenergy to fuel the future. Trends Plant Sci 13(8):421-429

41. Yevich R, Logan JA (2003) An assessment of biofuel use and burning of agricultural waste in the developing world. Glob Biogeochem Cycles. doi:10.1029/2002GB001952

42. Ensinas AV, Nebra SA, Lozano MA, Serra LM (2007) Analysis of process steam demand reduction and electricity generation in sugar and ethanol production from sugarcane. Energy Convers Manag 48(11):2978-2987

43. Khatiwada D, Leduc S, Silveira S, McCallum I (2016) Optimizing ethanol and bioelectricity production in sugarcane biorefineries in Brazil. Renew Energy 85:371-386

44. Sannigrahi P, Ragauskas AJ, Tuskan GA (2010) Poplar as a feedstock for biofuels: a review of compositional characteristics. Biofuels Bioprod Biorefin 4(2):209-226

45. Tharakan P, Volk T, Abrahamson L, White E (2003) Energy feedstock characteristics of willow and hybrid poplar clones at harvest age. Biomass Bioenergy 25(6):571-580

46. Sanderson MA, Adler PR (2008) Perennial forages as second generation bioenergy crops. Int J Mol Sci 9(5):768-788

47. Gustafsson C, Govindarajan S, Minshull J (2004) Codon bias and heterologous protein expression. Trends Biotechnol 22(7):346353

48. Perlak FJ, Fuchs RL, Dean DA, McPherson SL, Fischhoff DA (1991) Modification of the coding sequence enhances plant expression of insect control protein genes. Proc Natl Acad Sci 88(8): 3324-3328

49. Patel M, Johnson JS, Brettell RI, Jacobsen J, Xue G-P (2000) Transgenic barley expressing a fungal xylanase gene in the endosperm of the developing grains. Mol Breed 6(1):113-124

50. Batard Y, Hehn A, Nedelkina S, Schalk M, Pallett K, Schaller H, Werck-Reichhart D (2000) Increasing expression of P450 and P450-reductase proteins from monocots in heterologous systems. Arch Biochem Biophys 379(1):161-169

51. Hernandez-Garcia CM, Finer JJ (2014) Identification and validation of promoters and cis-acting regulatory elements. Plant Sci 217:109-119

52. Jain SM, Minocha SC (2013) Regulation of gene expression. In: Molecular biology of woody plants, vol 1. Springer Science \& Business Media, Berlin, pp. 6-8

53. Ziegelhoffer T, Will J, Austin-Phillips S (1999) Expression of bacterial cellulase genes in transgenic alfalfa (Medicago sativa L.), potato (Solanum tuberosum L.) and tobacco (Nicotiana tabacum L.). Mol Breed 5(4):309-318

54. Dai Z, Hooker BS, Anderson DB, Thomas SR (2000) Improved plant-based production of $\mathrm{E} 1$ endoglucanase using potato: expression optimization and tissue targeting. Mol Breed 6(3):277-285

55. Harrison MD, Geijskes J, Coleman HD, Shand K, Kinkema M, Palupe A, Hassall R, Sainz M, Lloyd R, Miles S (2011) Accumulation of recombinant cellobiohydrolase and endoglucanase in the leaves of mature transgenic sugar cane. Plant Biotechnol J 9(8):884-896

56. Chou H, Dai Z, Hsieh C, Ku M (2011) High level expression of Acidothermus cellulolyticus beta-1, 4-endoglucanase in transgenic rice enhances the hydrolysis of its straw by cultured cow gastric fluid. Biotechnol Biofuels 4:58

57. Xue G, Patel M, Johnson J, Smyth D, Vickers C (2003) Selectable marker-free transgenic barley producing a high level of cellulase 
(1, 4- $\beta$-glucanase) in developing grains. Plant Cell Rep 21(11): 1088-1094

58. Kim S, Lee D-S, Choi IS, Ahn S-J, Kim Y-H, Bae H-J (2010) Arabidopsis thaliana Rubisco small subunit transit peptide increases the accumulation of Thermotoga maritima endoglucanase Cel5A in chloroplasts of transgenic tobacco plants. Transgenic Res 19(3):489-497

59. Klose H, Gunl M, Usadel B, Fischer R, Commandeur U (2013) Ethanol inducible expression of a mesophilic cellulase avoids adverse effects on plant development. Biotechnol Biofuels 6(1):53

60. Streatfield S (2007) Approaches to achieve high-level heterologous protein production in plants. Plant Biotechnol J 5:2-15

61. Koziel MG, Carozzi NB, Desai N (1996) Optimizing expression of transgenes with an emphasis on post-transcriptional events. In: Post-transcriptional control of gene expression in plants. Springer, Berlin Heidelberg New York, pp. 393-405

62. Jobling SA, Gehrke L (1987) Enhanced translation of chimaeric messenger RNAs containing a plant viral untranslated leader sequence. Nature 325(6105):622-625

63. Datla RS, Bekkaoui F, Hammerlindl JK, Pilate G, Dunstan DI, Crosby WL (1993) Improved high-level constitutive foreign gene expression in plants using an AMV RNA4 untranslated leader sequence. Plant Sci 94(1):139-149

64. Dai Z, Hooker B, Quesenberry R, Thomas S (2005) Optimization of Acidothermus cellulolyticus endoglucanase (E1) production in transgenic tobacco plants by transcriptional, post-transcription and post-translational modification. Transgenic Res 14(5):627-643. doi: $10.1007 / \mathrm{s} 11248-005-5695-5$

65. Maliga P (2004) Plastid transformation in higher plants. Annu Rev Plant Biol 55:289-313

66. Bock R (2014) Genetic engineering of the chloroplast: novel tools and new applications. Curr Opin Biotechnol 26:7-13

67. Cardi T, Lenzi P, Maliga P (2010) Chloroplasts as expression platforms for plant-produced vaccines. Expert Rev Vaccines 9(8):893-911

68. Jung S, Lee D-S, Kim Y-O, Joshi CP, Bae H-J (2013) Improved recombinant cellulase expression in chloroplast of tobacco through promoter engineering and 5 ' amplification promoting sequence. Plant Mol Biol 83(4-5):317-328

69. Petersen K, Bock R (2011) High-level expression of a suite of thermostable cell wall-degrading enzymes from the chloroplast genome. Plant Mol Biol 76(3-5):311-321

70. Gray B, Bougri O, Carlson A, Meissner J, Pan S, Parker M, Zhang D, Samoylov V, Ekborg N, Michael Raab R (2011) Global and grain-specific accumulation of glycoside hydrolase family 10 xylanases in transgenic maize (Zea mays). Plant Biotechnol J 9: $1100-1108$

71. Mortimer CL, Dugdale B, Dale JL (2015) Updates in inducible transgene expression using viral vectors: from transient to stable expression. Curr Opin Biotechnol 32:85-92. doi:10.1016/j. copbio.2014.11.009

72. Caddick MX, Greenland AJ, Jepson I, Krause K-P, Qu N, Riddell KV, Salter MG, Schuch W, Sonnewald U, Tomsett AB (1998) An ethanol inducible gene switch for plants used to manipulate carbon metabolism. Nat Biotechnol 16(2):177-180. doi:10.1038 /nbt0298-177

73. Shen B, Sun X, Zuo X, Shilling T, Apgar J, Ross M, Bougri O, Samoylov V, Parker M, Hancock E (2012) Engineering a thermoregulated intein-modified xylanase into maize for consolidated lignocellulosic biomass processing. Nat Biotechnol 30(11): $1131-1136$

74. Marcia MO, Langdon T, Dalton S, Morris P (2012) Expression of a Trichoderma reesei $\beta-1,4$ endo-xylanase in tall fescue modifies cell wall structure and digestibility and elicits pathogen defence responses. Planta 236(6):1757-1774
75. Marcia MdO, Dalton S, Langdon T, Timms-Taravella E, Shearer EA, Morris P (2015) Functional co-expression of a fungal ferulic acid esterase and a $\beta-1,4$ endoxylanase in Festuca arundinacea (tall fescue) modifies post-harvest cell wall deconstruction. Planta: $1-15$

76. Lasa I, Berenguer J (1993) Thermophilic enzymes and their biotechnological potential. Microbiologia 9(2):77-89

77. Oraby H, Venkatesh B, Dale B, Ahmad R, Ransom C, Oehmke J, Sticklen M (2007) Enhanced conversion of plant biomass into glucose using transgenic rice-produced endoglucanase for cellulosic ethanol. Transgenic Res 16(6):739-749

78. Ransom C, Balan V, Biswas G, Dale B, Crockett E, Sticklen M (2007) Heterologous Acidothermus cellulolyticus 1, 4- $\beta$ endoglucanase E1 produced within the corn biomass converts corn stover into glucose. In: Applied biochemistry and Biotecnology. Springer, Berlin Heidelberg New York, pp. 207219

79. Biswas GCG, Ransom C, Sticklen M (2006) Expression of biologically active Acidothermus cellulolyticus endoglucanase in transgenic maize plants. Plant Sci 171(5):617-623

80. Kim S, Kim Y-O, Lee Y, Choi I, Joshi CP, Lee K, Bae H-J (2012) The transgenic poplar as an efficient bioreactor system for the production of xylanase. Biosci Biotechnol Biochem 76(6):1140 1145

81. Kimura T, Mizutani T, Tanaka T, Koyama T, Sakka K, Ohmiya K (2003) Molecular breeding of transgenic rice expressing a xylanase domain of the xynA gene from Clostridium thermocellum. Appl Microbiol Biotechnol 62(4):374-379

82. Kimura T, Mizutani T, Sun J-L, Kawazu T, Karita S, Sakka M, Kobayashi Y, Ohmiya K, Sakka K (2010) Stable production of thermotolerant xylanase B of Clostridium stercorarium in transgenic tobacco and rice. Biosci Biotechnol Biochem 74(5):954 960

83. Harrison MD, Zhang Z, Shand K, Chong BF, Nichols J, Oeller P, O'Hara IM, Doherty WO, Dale JL (2014) The combination of plant-expressed cellobiohydrolase and low dosages of cellulases for the hydrolysis of sugar cane bagasse. Biotechnol Biofuels 7(1): 131

84. Gandla ML, Derba-Maceluch M, Liu X, Gerber L, Master ER, Mellerowicz EJ, Jönsson LJ (2015) Expression of a fungal glucuronoyl esterase in Populus: effects on wood properties and saccharification efficiency. Phytochemistry 112:210-220

85. Badhan A, Jin L, Wang Y, Han S, Kowalczys K, Brown DC, Ayala CJ, Latoszek-Green M, Miki B, Tsang A (2014) Expression of a fungal ferulic acid esterase in alfalfa modifies cell wall digestibility. Biotechnol Biofuels 7(1):39

86. Buanafina MMdO, Langdon T, Dalton S, Morris P (2012) Expression of a Trichoderma reesei $\beta-1,4$ endo-xylanase in tall fescue modifies cell wall structure and digestibility and elicits pathogen defence responses. Planta:1-18

87. Pogorelko G, Lionetti V, Fursova O, Sundaram RM, Qi M, Whitham SA, Bogdanove AJ, Bellincampi D, Zabotina OA (2013) Arabidopsis and Brachypodium distachyon transgenic plants expressing Aspergillus nidulans acetylesterases have decreased degree of polysaccharide acetylation and increased resistance to pathogens. Plant Physiol 162(1):9-23

88. Perlack RD, Wright LL, Turhollow AF, Graham RL, Stokes BJ, Erbach DC (2005) Biomass as feedstock for a bioenergy and bioproducts industry: the technical feasibility of a billion-ton annual supply. DTIC Document

89. Humbird D, Davis R, Tao L, Kinchin C, Hsu D, Aden A, Schoen P, Lukas J, Olthof B, Worley M (2011) Process design and economics for biochemical conversion of lignocellulosic biomass to ethanol: dilute-acid pretreatment and enzymatic hydrolysis of corn stover. National Renewable Energy Laboratory (NREL), Golden, $\mathrm{CO}$ 
90. Brunecky R, Selig MJ, Vinzant TB, Himmel ME, Lee D, Blaylock MJ, Decker SR (2011) In planta expression of A. cellulolyticus $\mathrm{Cel} 5 \mathrm{~A}$ endocellulase reduces cell wall recalcitrance in tobacco and maize. Biotechnol Biofuels 4(1):1-11

91. Zhang D, VanFossen AL, Pagano RM, Johnson JS, Parker MH, Pan S, Gray BN, Hancock E, Hagen DJ, Lucero HA (2011) Consolidated pretreatment and hydrolysis of plant biomass expressing cell wall degrading enzymes. BioEnergy Res 4(4):276286

92. Yang B, Wyman CE (2008) Pretreatment: the key to unlocking low-cost cellulosic ethanol. Biofuels Bioprod Biorefin 2(1):26-40

93. Alvira P, Tomás-Pejó E, Ballesteros M, Negro M (2010) Pretreatment technologies for an efficient bioethanol production process based on enzymatic hydrolysis: a review. Bioresour Technol 101(13):4851-4861

94. Taherzadeh MJ, Karimi K (2008) Pretreatment of lignocellulosic wastes to improve ethanol and biogas production: a review. Int $\mathrm{J}$ Mol Sci 9(9):1621-1651

95. Sunna A, Moracci M, Rossi M, Antranikian G (1997) Glycosyl hydrolases from hyperthermophiles. Extremophiles 1(1):2-13

96. Marzialetti T, Valenzuela Olarte MB, Sievers C, Hoskins TJ, Agrawal PK, Jones CW (2008) Dilute acid hydrolysis of Loblolly pine: a comprehensive approach. Ind Eng Chem Res 47(19):7131-7140

97. Chang VS, Nagwani M, Holtzapple MT (1998) Lime pretreatment of crop residues bagasse and wheat straw. Appl Biochem Biotechnol 74(3):135-159

98. Montenecourt BS (1983) Trichoderma reesei cellulases. Trends Biotechnol 1(5):156-161

99. Li D, Li X, Dang W, Tran PL, Park S-H, Oh B-C, Hong W-S, Lee J-S, Park K-H (2013) Characterization and application of an acidophilic and thermostable $\beta$-glucosidase from Thermofilum pendens. J Biosci Bioeng 115(5):490-496

100. Trivedi N, Gupta V, Kumar M, Kumari P, Reddy C, Jha B (2011) Solvent tolerant marine bacterium Bacillus aquimaris secreting organic solvent stable alkaline cellulase. Chemosphere 83(5): 706-712

101. Zhao X, Cheng K, Liu D (2009) Organosolv pretreatment of lignocellulosic biomass for enzymatic hydrolysis. Appl Microbiol Biotechnol 82(5):815-827

102. Chong BF, Harrison MD, O'Hara IM (2014) Stability of endoglucanases from mesophilic fungus and thermophilic bacterium in acidified polyols. Enzym Microb Technol 61:55-60

103. Li X, Yu H-Y (2012) Purification and characterization of an organic-solvent-tolerant cellulase from a halotolerant isolate, Bacillus sp. L1. J Ind Microbiol Biotechnol 39(8):1117-1124

104. Dadi AP, Varanasi S, Schall CA (2006) Enhancement of cellulose saccharification kinetics using an ionic liquid pretreatment step. Biotechnol Bioeng 95(5):904-910

105. Engel P, Mladenov R, Wulfhorst H, Jäger G, Spiess AC (2010) Point by point analysis: how ionic liquid affects the enzymatic hydrolysis of native and modified cellulose. Green Chem 12(11): 1959-1966

106. Ilmberger N, Meske D, Juergensen J, Schulte M, Barthen P, Rabausch U, Angelov A, Mientus M, Liebl W, Schmitz RA (2012) Metagenomic cellulases highly tolerant towards the presence of ionic liquids - linking thermostability and halotolerance. Appl Microbiol Biotechnol 95(1):135-146

107. Adsul MG, Terwadkar AP, Varma AJ, Gokhale D (2009) Cellulases from Penicillium janthinellum mutants: solid-state production and their stability in ionic liquids. Bioresources 4(4): $1670-1681$

108. Arnold FH (1993) Protein engineering for unusual environments. Curr Opin Biotechnol 4(4):450-455

109. Jansson S, Douglas CJ (2007) Populus: a model system for plant biology. Annu Rev Plant Biol 58:435-458
110. Palin RJ (2011) A comparison of cell wall properties of Arabidopsis thaliana. Dissertation, University of Birmingham

111. Chaffey N, Cholewa E, Regan S, Sundberg B (2002) Secondary xylem development in Arabidopsis: a model for wood formation. Physiol Plant 114(4):594-600

112. Pauly M, Keegstra K (2008) Cell-wall carbohydrates and their modification as a resource for biofuels. Plant J 54(4):559-568

113. Tsai AYL, Canam T, Gorzsás A, Mellerowicz EJ, Campbell MM, Master ER (2012) Constitutive expression of a fungal glucuronoyl esterase in Arabidopsis reveals altered cell wall composition and structure. Plant Biotechnol J 10(9):1077-1087

114. Prado JR, Segers G, Voelker T, Carson D, Dobert R, Phillips J, Cook K, Cornejo C, Monken J, Grapes L (2014) Genetically engineered crops: from idea to product. Annu Rev Plant Biol 65: 769-790

115. Hématy K, Cherk C, Somerville S (2009) Host-pathogen warfare at the plant cell wall. Curr Opin Plant Biol 12(4):406-413

116. Vorwerk S, Somerville S, Somerville C (2004) The role of plant cell wall polysaccharide composition in disease resistance. Trends Plant Sci 9(4):203-209

117. Bi C, Chen F, Jackson L, Gill BS, Li W (2011) Expression of lignin biosynthetic genes in wheat during development and upon infection by fungal pathogens. Plant Mol Biol Report 29(1):149 161

118. Tronchet M, Balague C, Kroj T, Jouanin L, Roby D (2010) Cinnamyl alcohol dehydrogenases-C and D, key enzymes in lignin biosynthesis, play an essential role in disease resistance in Arabidopsis. Mol Plant Pathol 11(1):83-92

119. Derikvand MM, Sierra JB, Ruel K, Pollet B, Do C-T, Thévenin J, Buffard D, Jouanin L, Lapierre C (2008) Redirection of the phenylpropanoid pathway to feruloyl malate in Arabidopsis mutants deficient for cinnamoyl-CoA reductase 1. Planta 227(5):943956

120. Baucher M, Bernard-vailhé M, Chabbert B, Besle J-M, Opsomer C, Van Montagu M, Botterman J (1999) Down-regulation of cinnamyl alcohol dehydrogenase in transgenic alfalfa (Medicago sativa $L$.) and the effect on lignin composition and digestibility. Plant Mol Biol 39(3):437-447. doi:10.1023/A:1006182925584

121. Leple J-C, Dauwe R, Morreel K, Storme V, Lapierre C, Pollet B, Naumann A, Kang K-Y, Kim H, Ruel K (2007) Downregulation of cinnamoyl-coenzyme A reductase in poplar: multiple-level phenotyping reveals effects on cell wall polymer metabolism and structure. Plant Cell 19(11):3669-3691

122. Shen H, He X, Poovaiah CR, Wuddineh WA, Ma J, Mann DG, Wang H, Jackson L, Tang Y, Neal Stewart C (2012) Functional characterization of the switchgrass (Panicum virgatum) R2R3MYB transcription factor $P v M Y B 4$ for improvement of lignocellulosic feedstocks. New Phytol 193(1):121-136

123. Baxter HL, Poovaiah CR, Yee KL, Mazarei M, Rodriguez Jr M, Thompson OA, Shen H, Turner GB, Decker SR, Sykes RW (2015) Field Evaluation of Transgenic Switchgrass Plants Overexpressing $P v M Y B 4$ for Reduced Biomass Recalcitrance. BioEnergy Research:1-12

124. Öhgren K, Bura R, Saddler J, Zacchi G (2007) Effect of hemicellulose and lignin removal on enzymatic hydrolysis of steam pretreated corn stover. Bioresour Technol 98(13):2503-2510

125. Gallardo F, Fu J, Cantón FR, García-Gutiérrez A, Cánovas FM, Kirby EG (1999) Expression of a conifer glutamine synthetase gene in transgenic poplar. Planta 210(1):19-26

126. Kumar R, Wyman CE (2009) Effect of xylanase supplementation of cellulase on digestion of corn stover solids prepared by leading pretreatment technologies. Bioresour Technol 100(18):4203-4213

127. Karimi K, Emtiazi G, Taherzadeh MJ (2006) Ethanol production from dilute-acid pretreated rice straw by simultaneous saccharification and fermentation with Mucor indicus, Rhizopus oryzae, and 
Saccharomyces cerevisiae. Enzym Microb Technol 40(1):138144

128. Keshwani DR, Cheng JJ (2009) Switchgrass for bioethanol and other value-added applications: a review. Bioresour Technol 100(4):1515-1523

129. Dhindsa RS, Plumb-Dhindsa P, Thorpe TA (1981) Leaf senescence: correlated with increased levels of membrane permeability and lipid peroxidation, and decreased levels of superoxide dismutase and catalase. J Exp Bot 32(1):93-101

130. Bals B, Teachworth L, Dale B, Balan V (2007) Extraction of proteins from switchgrass using aqueous ammonia within an integrated biorefinery. Appl Biochem Biotechnol 143(2):187-198

131. Leelavathi S, Gupta N, Maiti S, Ghosh A, Reddy VS (2003) Overproduction of an alkali-and thermo-stable xylanase in tobacco chloroplasts and efficient recovery of the enzyme. Mol Breed 11(1):59-67

132. Hefferon K (2014) Plant virus expression vector development: new perspectives. BioMed research international 2014 doi: $10.1155 / 2014 / 785382$

133. Hefferon KL (2014) DNA virus vectors for vaccine production in plants: spotlight on geminiviruses. Vaccines 2(3):642-653

134. Chapman S, Kavanagh T, Baulcombe D (1992) Potato virus X as a vector for gene expression in plants. Plant J 2(4):549-557

135. Gleba Y, Marillonnet S, Klimyuk V (2004) Engineering viral expression vectors for plants: the 'full virus' and the 'deconstructed virus' strategies. Curr Opin Plant Biol 7(2):182-188. doi:10.1016 j.pbi.2004.01.003
136. Porta C, Lomonossoff GP (2002) Viruses as vectors for the expression of foreign sequences in plants. Biotechnol Genet Eng Rev 19(1):245-292

137. Scholthof K-BG, Mirkov TE, Scholthof HB (2002) Plant virus gene vectors: biotechnology applications in agriculture and medicine. In: Genetic engineering. Springer, Berlin Heidelberg New York, pp. 67-85

138. Gleba Y, Klimyuk V, Marillonnet S (2007) Viral vectors for the expression of proteins in plants. Curr Opin Biotechnol 18(2):134 141

139. Hefferon KL (2012) Plant virus expression vectors set the stage as production platforms for biopharmaceutical proteins. Virology 433(1): $1-6$

140. Scholthof HB, Scholthof K-BG, Jackson AO (1996) Plant virus gene vectors for transient expression of foreign proteins in plants. Annu Rev Phytopathol 34(1):299-323

141. Dawson WO, Folimonova SY (2013) Virus-based transient expression vectors for woody crops: a new frontier for vector design and use. Annu Rev Phytopathol 51:321-337

142. Dugdale B, Mortimer CL, Kato M, James TA, Harding RM, Dale JL (2013) In plant activation: an inducible, hyperexpression platform for recombinant protein production in plants. Plant Cell 25(7):2429-2443

143. Espinoza-Sánchez EA, Torres-Castillo JA, Rascón-Cruz Q, Zavala-García F, Sinagawa-García SR (2016) Production and characterization of fungal $\beta$-glucosidase and bacterial cellulases by tobacco chloroplast transformation. Plant Biotechnol Rep 10(2):61-73 